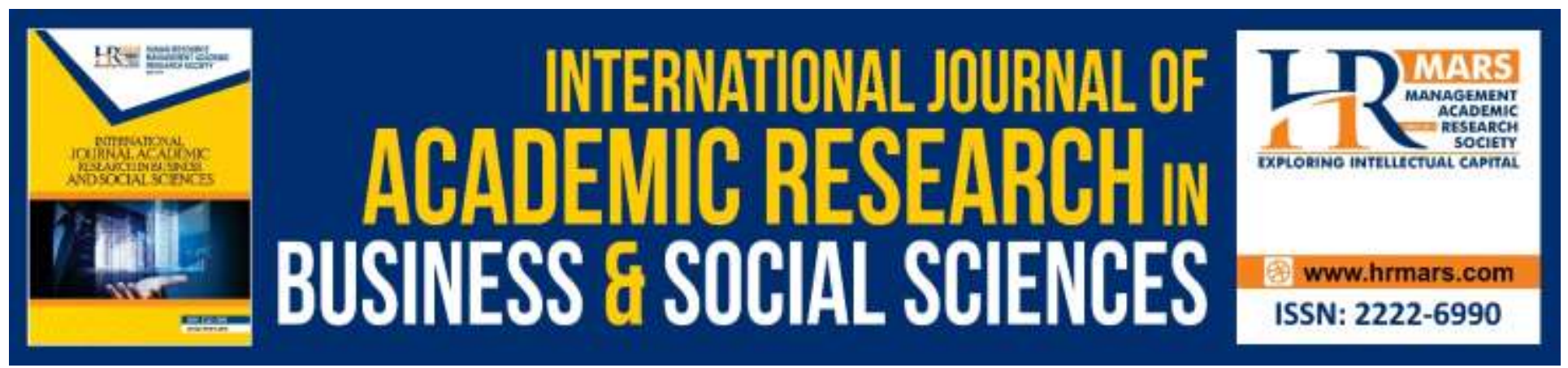

\title{
Preventive Legal Procedures in Maintaining the Permanence of the Islamic Marriage Contract: Malaysian Experience
}

Ahmed S.A. AIQodsi, Sharifah Norshah Bani Syed Bidin, Mohammed
Muneer'deen Olodo Al-Shafi'l, Tengku Fatimah Muliana Tengku Muda

To Link this Article: http://dx.doi.org/10.6007/IJARBSS/v10-i4/7143

DOI:10.6007/IJARBSS/v10-i4/7143

Received: 04 February 2020, Revised: 22 March 2020, Accepted: 12 March 2020

Published Online: 12 April 2020

In-Text Citation: (AlQodsi et al., 2020)

To Cite this Article: AlQodsi, A. S. A., Bidin, S. N. B. S., Al-Shafi'I, M. M. O., \& Muda, T. F. M. T. (2020). Preventive Legal Procedures in Maintaining the Permanence of The Islamic Marriage Contract: Malaysian Experience. International Journal of Academic Research in Business and Social Sciences, 10(4), 408-420.

Copyright: (C) 2020 The Author(s)

Published by Human Resource Management Academic Research Society (www.hrmars.com)

This article is published under the Creative Commons Attribution (CC BY 4.0) license. Anyone may reproduce, distribute, translate and create derivative works of this article (for both commercial and non-commercial purposes), subject to full attribution to the original publication and authors. The full terms of this license may be seen

at: http://creativecommons.org/licences/by/4.0/legalcode

Vol. 10, No. 4, 2020, Pg. 408 - 420

http://hrmars.com/index.php/pages/detail/IJARBSS

JOURNAL HOMEPAGE

Full Terms \& Conditions of access and use can be found at http://hrmars.com/index.php/pages/detail/publication-ethics 


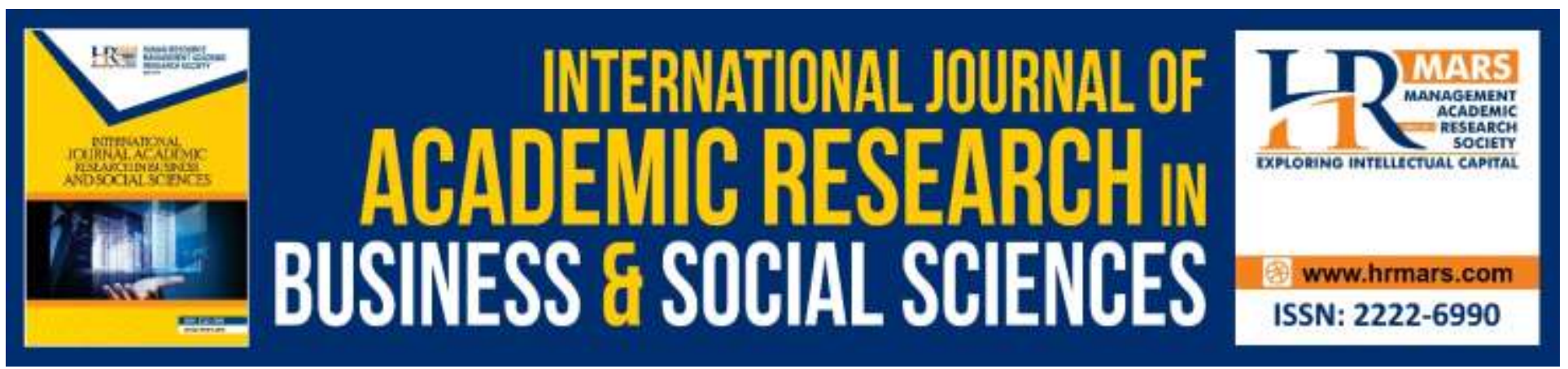

\title{
Preventive Legal Procedures in Maintaining the Permanence of The Islamic Marriage Contract: Malaysian Experience
}

\author{
Ahmed S.A. AlQodsi ${ }^{1}$, Sharifah Norshah Bani Syed Bidin², \\ Mohammed Muneer'deen Olodo Al-Shafi'i², Tengku Fatimah Muliana \\ Tengku Muda² \\ ${ }^{1}$ University College Darul Quran Islamiah, 21200 Kuala Terengganu, Malaysia. \\ ${ }^{2}$ Faculty of Islamic Contemporary Studies, Universiti Sultan Zainal Abidin Gong Badak \\ Campus, 21300 Kuala Nerus, Terengganu, Malaysia
}

\section{Abstract}

The Islamic Shari'a law has approved the establishment of marriage tie, as well as surrounded it with a set of preventive legal measures to ensure its permanence and continuity, in order to achieve the desired interest of the couple and to achieve happiness in the Muslim family. Most especially in the times that divorce has become common and rampant in the Muslim countries. This qualitative study which based on document analysis, is aimed at clarifying preventive legal procedures in maintaining the permanence of the marriage, both before and after the marriage tie, in the hope of building a family filled with love, interdependence and tranquillity. Few selected Shariah divorce cases in Malaysia are also discussed to reflect the Malaysian experience. The study found that the legal perception of preventive measures and procedures required before the marriage. These include: the basis of each spouse's choice of the other; the necessity of respecting the result of the medical examination; and taking care of the pre-marital engagement. It also found the establishing preventive legal measure after the marriage. These include: taking care of the rights of the wife, such as the dower, maintenance and housing; taking care of the rights of the husband, such as obedience, mandate of discipline, and settlement in the house and in the giving service; and taking care of the common rights of the spouses in good relation, and the right to filial enjoyment and inviolability of the marriage.

Keywords: Preventive Measures, Marriage Tie, Divorce, Dower, Marriage

\section{Introduction}

Allah The Almighty has created mankind with honor, and Islamic Shari'ah has approved many provisions that guarantee the permanence of the marriage tie and help in the stability of marital life. This is in order to have a happy family free of discord and divorce, which follows the path of Allah, to 
INTERNATIONAL JOURNAL OF ACADEMIC RESEARCH IN BUSINESS AND SOCIAL SCIENCES Vol. 10, No. 4, April, 2020, E-ISSN: 2222-6990 @ 2020 HRMARS

achieve the benefits of man through the important legislations of marriage and high respect among the people, in order to emerge new generation carrying on the Islamic heritage and civilization, as well as performs its duties in the best way.

However, many marriages across countries have ended in separation and divorce. Studies prove that there are many factors that can lead to divorce (South \& Spitze, 1986; Amato, 2003; Zemp \& Bodenmann, 2018). In fact, prior to the divorce, spouses may have experienced the 'emotional divorce' phase between them long before they decided to end the marriage. An emotional divorce or disengagement could then cause the attraction, affection and beliefs between the spouses to decline. This level is also known as 'empty shell' whereas couples are still living together, but their physical and emotional relationships are very minimal (Parker, 1993; Nimtz, 2011) until finally it resulted in divorce. Marital violence resulting to divorce has also been rampant in many countries nowadays. This phenomenon does not exclude Malaysia, a multi-cultural and multi-religious country in the South-east Asian region. Islam represents one of the most widely professed religion in Malaysia recorded at $61.7 \%$ from its population (www.indexmundi.com).

According to statistics released by Royal Malaysia Police (RMP), a number of 18124 cases of marital abuse were reported in Malaysia from 2007 until 2011, in which 3277 cases were reported in 2011 and an alarming 506 cases for the first two months of 2012 (mStar Online, 2012). The divorce dispute among Muslims in Malaysia has become a major problem, as reported in Utusan newspaper dated $11^{\text {th }}$ October, 2017, where it appeared that between 2014 and 2017, a total of 171,252 divorce cases were recorded (Bakar 2017). According to the Marriage and Divorce Statistics, Malaysia, the number of Muslim divorces recorded in 2017 was 39,709, decreased 3.2 per cent as compared to 41,030 in 2016. On the hand, the 5th Population and Family Survey conducted by the National Population and Family Development Board of Malaysia found that, the first five years of marriage is the most challenging term for couples where couples may face financial struggle, marital responsibilities and adaptation to the new life struggle.

These official statistics of divorces in Malaysia reflect the existence of a real problem between couples leading to quarrel and divorce. This study is therefore intended to demonstrate the preventive legal procedures as outlined in Islam to ensure the permanence of the marriage tie, which shows the legal perception of preventive measures and procedures required before and after the marriage.

\section{Marriage and Divorce Under the Islamic Family Law in Malaysia}

Malaysia has a dual legal system which practices a civil legal system and an Islamic (Shariah) legal system. Article $121(1 \mathrm{~A})$ of the Federal Constitution states that the civil courts have no jurisdiction over matters that are within the jurisdiction of the Shariah Courts. Thus, matters governed under Islamic laws are only to be administered through Shariah Courts. Unlike civil law, which is federal law, Islamic law is state based. As such, Islamic laws may vary from state to state, although most hold similar to identical provisions on particular matters. Relatively, muslim marriages must be contracted and regulated under the Islamic family laws of each of the states. Section 8 of Islamic Family Law (Federal Territories) Act 1984 stipulates the minimum age of marriage for Muslims to be 18 years for 
INTERNATIONAL JOURNAL OF ACADEMIC RESEARCH IN BUSINESS AND SOCIAL SCIENCES Vol. 10, No. 4, April, 2020, E-ISSN: 2222-6990 @ 2020 HRMARS

boys and 16 years for girls. However, an exception is provided that allows a child under those ages to marry with the consent of the Shariah Court. In normal cases, the consent of a wali must be obtained prior to a marriage.

The issue of refusal of a wali to marry off his daughter can best be described in the case of Marlia Akmar bt Ramli v Ramli bin Abdul Rahman (1431)30(2)JH 237. The applicant, aged 27 and a degree holder, made an application to the court to allow the wali hakim to solemnize her marriage on the ground that the respondent, her wali refused to marry her off. To determine whether there was such an issue on refusal of wali, the court referred to the book of Hasyiah l'anah at-Talibin and summarized that there are five conditions to declare that a wali has refused to marry off the woman under his care. The conditions are; the woman is mukallaf, the woman's choice is in equal social status as her, the prospective husband is a specific person and that there is refusal from wali mujbir to marry her off, except due to the reason that the wali has another choice eventhough his choice is lesser in equal social status as compared to her own choice. The court dealt extensively with the third condition since the ground of refusal by the respondent in his affidavit was that the man was not on equal social status with his daughter in terms of qualification, religion, career and income. The man chosen by the daughter was 19 years older than her. She was an executive with a monthly income of more than RM2,000 while the man was a member of the stage crew at Istana Budaya, whose income was lesser than the applicant. The respondent also claim that the man was not among the pious; that he was a womanizer and hot tempered. The respondent however failed to prove his accusations. In allowing the marriage to be solemnized by wali hakim, the court viewed that there is no issue of kafaah regarding the age gap, and the court was also satisfied that their type of work was equal even though the respondent's salary was slightly higher. It can be inferred that the court relied on the views of the Muslim scholars that a reasonable justification is necessary if a wali refuses to marry off her daughter. Submittedly, the court is also careful in interpreting the issue on kafaah as it serves as one preventive measures encouraged by Islam prior to tying a knot between a man and a woman in marriage.

Among notable types of dissolution of marriage in Malaysia is fasakh where the law provides a number of grounds entitling a wife for divorce in an unseccessful marriage. In the case of Zakhlina bt Khalid $v$ Noasmadi bin Abdullah ${ }^{1}$, the wife claimed for an application of fasakh divorce on the ground that the husband had treated her with cruelty and that he was having an affair with another woman. The learned judge, Mat Ropi Busu in allowing the application stressed that;

"It is not the purpose of marriage in Islam to force parties to live in misery and cruelty in a marriage that they disliked...if a particular marriage fails and its sacred aim and purpose could not be achieved, and instead results in harm, distress and difficulties among others, then it is appropriate for the marriage to be dissolved"

In the case of Belinda binti Adnan and Shahrul Nizam bin Awalludin, ([2013]3 ShLR 100) the plaintiff applied for a fasakh divorce on two grounds namely; failure of the husband to provide maintenance

${ }^{1}$ [2013]3 ShLR 100 
for more than 3 months and that the husband had treated her with cruelty and making her life miserable. The wife claimed to be mentally and physically abused by the husband and was often slapped and beaten. In one occasion the husband had thrown a chair to her when she questioned the husband's habit of gambling and getting drunk. A police report was lodged by the wife. Due to her depression, she had also undergone a counseling and therapy session at Kuala Lumpur Hospital. The learned trial judge satisfied that the defendant's conduct has inflicted darar on the plaintiff's life. The court then allowed the application and granted fasakh.

In another case of Noor Aishah binti Ali Akbar v Mohd Shahnaz bin Mohd Amin (Mal Case 0530/2013, Syariah Court of Gombak Timur, Malaysia), a fasakh application was made on the ground of failure of the husband to provide maintenance for more than 3 months since January 2013 until July 2013, habitually assaults her and make her life miserable by cruelty of conduct, and obstruct her in the observance of religious obligations. In this case, the parties were married in June 2012. The plaintiff claimed that the defendant started neglecting to provide maintenance since July 2012, approximately a month after their marriage. The plaintiff would have to ask for her maintenance which often resulted in the defendant assaulted her by slapping, beating, shouting and verbally abusing by way of insult. The plaintiff was often disrespectfully called as jalang (bitch), sial (ill-fated), bodoh (stupid)and cursed to hell. In few occasions the plaintiff was slapped until she became fainted. The plaintiff was also obstructed from observing religious obligations such as praying. The application was allowed and the marriage was dissolved through fasakh.

The above cases are only a few examples of current marital crisis. The cases illustrate that eventhough the law strives at protecting the marriage institutions throuugh judicial sanctions, the law itself will not be effective should the individuals to the marriage fail to appreciate the objectives as sanctioned by Islam. In fact, Islam has outlined a set of preventive legal measures to be observed prior and after marriage contract for the permanence of the marital relationship.

\section{Preventive Legal Procedures Before the Marriage}

The basis for preventive measures are, the right to choose of each of the spouses for the other, the need to respect the result of the medical examination, and the protection of Marriage introductory promise, which is explained as follows:

\section{The First Requirement: The Legal Perception on The Spouses Choosing Each Other}

Marriage in Islam is the means for establishing a family and for that Islam has proposed several attributes to be considered in choosing a future wife:

a. The woman be of good character and religion

A good wife obeys her husband, upholds his right, and preserves herself and his money in his absence. It is narrated from 'Abdullah ibn Amru (may Allah be pleased with them) that the Messenger of Allah (peace and blessings of Allah be upon him) said: "The worldly-life is filled with pleasure, and the best of the worldly-life pleasures are good women" (Muslim, 1334H/2: 1467). It was also narrated by Abu Hurayrah (may Allah be pleased with him) that the Prophet (peace and blessings of Allah be upon him) said: "woman are married to four criteria; her wealth, her beauty, her family pedigree, and her religion, so prefer for yourself one with religion to be blessed" (Muslim, 1334H/2: 1466). 
b. To be a virgin and productive

It is desirable for a man when choosing his wife to choose her when she is virgin, that she had never been married, and that she is productive, giving birth to his children because the purpose of marriage is the production of offspring. It was narrated by Ma'qal ibn Yasar that a man came to the Messenger of Allah (peace and blessing be upon him) saying: I am in love with a woman of pedigree and rank, only that she cannot reproduce, may I marry her? The Messenger of Allah refused him. He came the second time and the Prophet refused him, and when he came the third time the Prophet said: "Get married to the lovingly and productive women, for I am with you a multitude nation" (Ibn-Hanbal, 2001/20: 12613). This is recognized in women through their health status, their youth, and their women relatives.

Perhaps the wisdom that led the Prophet (peace and blessing of Allah be upon him) to urge for virgins was the relation from Abdul Rahman bin Salim al-Ansari, through his father, and his grandfather, that the Messenger of Allah (peace and blessing of Allah be upon him) said: (you are urged to marry virgins, for their mouth are most freshen, have the purest wombs, and most pleased with little" (Ibn Majah, n.d/1: 1861).

Imam Abu Hamed al-Ghazali mentions several benefits in the virginity of women. They are: that the wife loves the husband, accompanies him, and influences the meaning of friendliness, and that it leads to the completion of the husband's affection for his wife, and that the wife does not misses the first husband because of his presence in her life (Al-Ghazali, n.d./ 2:38).

c. To be of a considerable dower

From amongst the signs of mercy and blessing in women is that they are of considerable dower. If there is any glory in exaggerating dowries, the Messenger of Allah (peace and blessing of Allah be upon him) would have been the first to do it. It was narrated by Ali that when he married Fatima to him he sent with her small mattress, leather pillow stuffed with fiber, and also other domestic materials (Al-Haythami, 1994/10: 99).

It is not mentioned in Islam specifically the least and the highest dower, but being moderate and considerable is something of a praiseworthy, because being too low downgrades the dignity and rights of the women, and being too much burdens the husband, and thus resulting to the loss of tranquility and happiness desired of marriage. This could also lead to enmity between the spouses, and could be source of argument for them.

Likewise, the right of choice given to men is equally given to women; her father or guardian have no right to force her on marriage if she is not interested. It is narrated that 'Abd-al-Rahmaan ibn Yazid and Ibn Yazid al-Ansari said: A man named Khudamah married his daughter to him, but she rejected her father's choice. She reported her father to the Messenger of Allah who cancelled her father's choice. She later married Aba Lubabah ibn 'Abd al-Mundhir (Ibn Majah, 1:1873). 
INTERNATIONAL JOURNAL OF ACADEMIC RESEARCH IN BUSINESS AND SOCIAL SCIENCES Vol. 10, No. 4, April, 2020, E-ISSN: 2222-6990 @ 2020 HRMARS

\section{Medical Examination Before Marriage}

One of the purposes of shari'ah in marriage is the preservation of the lineage when planning to have children, and it is meant to have offspring that are healthy and free from genetic and dangerous diseases. It is possible to have healthy offspring by choosing healthy wives. It was narrated by 'Aa'ishah (may Allah be pleased with her) that the Messenger of Allah (may peace and blessing of Allah be upon him) said: "Give to your children good preference, be married to the healthy women, and marry your daughters to healthy men" (Ibn Majah, 1: 1968), i. e. get for her the best and the most favourite suitor, that which is free from defection and immorality, through the medical examination before marriage.

The Islamic Shari'ah law calls for attention to health, for physical and rational strength is required for health and safety, just as weakness and humor are often linked to disease. So, Muslims must follow all the ways and means to avoid all that can happen the health through medical examination before marriage.

\section{Respect for Pre-Marital Engagement}

Marriage is one of the most important relations in Islamic shari'ah law, because it is based on family affairs, and thus pre-marital engagement, which is considered a precautionary measure that will reduce the divorce in the future, is initiated. The pre-marital engagement is defined as seeking for the marriage by the suitor towards the fiance (Sharbini 1994/3: 175).

The legality of the pre-marital engagement is supported by Allah in "there is no offence for you to propose marriage indirectly(by hinting) to such women(who husbands have passed away and are still in waiting period)" (al-Baqarah : 235). The Prophet (peace and blessings of Allah be upon him) also said: "If one of you approaches a woman, if he is able to look at what calls his interest to marrying, let him do so" (Abu Dawud 1975/2: 2082).

There are several conditions to approaching a woman for marriage in Islamic jurisprudence, they include: that the fiancée is not permanently or temporarily forbidden to marry, that she should not have been engaged by another person, and she is not under an 'iddah period for another man (al-Kasani 1986/3: 323).

The pre-marital engagement has many rulings. it includes: showing the importance of holding a marriage rite by preceding it with an engagement, it gives the women and their families an opportunity to inquire about the suitor in terms of his religious convictions, ethics and character. It allows both the suitor and the fiancée the opportunity of being accustomed to each other, and also allows stability and tranquility so that each of them would be assured of his/her lifetime partner.

\section{Preventive Legal Procedures After the Marriage Tie}

Marriage is a strong connection between men and women. It is structured to be permanent and everlasting. Hence, it is subject to some rights, some of which are specific to the wife and some of which are specific to the husband, and some are shared among them both. Allah says: "And women shall have rights similar to the rights against them, according to what is equitable but men have a 
INTERNATIONAL JOURNAL OF ACADEMIC RESEARCH IN BUSINESS AND SOCIAL SCIENCES Vol. 10, No. 4, April, 2020, E-ISSN: 2222-6990 @ 2020 HRMARS

degree(of advantage) over them" (al-Baqarah: 228). If each of the spouses upholds his/her responsibilities towards his lifetime partner, the family would be pleasant and be free of problems leading to divorce. Following are the explanations:

\section{The Rights of The Wife on Her Husband}

The rights of the wife on her husband can be divided into the following:

\section{a. The Dower}

Dower, in a conceptual term, is what women deserve in turn for marriage (Al-Omrani, 2000/9: 346). So dower is one of the rights of the wife from her husband because of the injunction of Allah which says: "And give the women(on marriage) their dower as a free gift" (al-Nisa': 4). Dower is obligatory on men for their control over their wives, and they are required to work to provide for the family, as a symbol and expression of their heart desired love towards their wives. At the same time, women are required to be faithful, obedient, and work to appease their husbands. The wisdom of dower legislation shows when a woman leaves her father's house to her husband's house to begin a new life. She would need some supplies that are suitable for this transition, such as clothes, ornaments, and others, and that is why it is important that the husband assists with the needed facilities, hence the obligation of paying dower to her (Abu-Zahrat, n.d).

It also shows the status and importance of marriage, as well as honouring the dignity of women and protecting them, which helps to perpetuate the continuity of the married life. When a man looks at his wife with respect and appreciates her by giving paying the dower, it is to give her a place in his heart, which quickens his place in her heart as well.

\section{b. Alimony}

Alimony, in a conceptual term, is food, clothing, and housing (Ibn-Abidin, 1966/3: 572). The Islamic Shari'ah law has demanded that the husband should take the responsibility of spending, taking into consideration his condition, both in difficulty and at ease, so that he is not emburdened with that which he could not during hardship, in order to safeguard the permanence of the marital life. This is the position of the Shafi'i scholars (Al-Sharbini, 1994/3: 550), relying on the words of Allah that says: "Let the men of means spend according to his means and the man whose resources are restricted. Let him spend according to what Allah has given him. Allah puts no burden on any person beyond what He has given him. After a difficulty Allah will soon grant relief" (al-Talaq: 7), and "...let the women live(in iddah) in the same style as ye live, according to your means" (al-Talaq: 6).

A good relationship between the spouses requires that the husband should not deprive his wife if she is in need, and it is obligatory that the wife does not exhaust her husband, so that she does not demand from him that which he could not afford. At the same time it the consensus of the scholars that it is obligatory on the affluent husband to provide for the wife, even if she is well-to-do, and the majority of scholars are of the view that it is also obligatory to spend on her, even if the husband is insolvent (al-Sharbini, 1994/3: 543; IbnQudamah, 1405/11: 201). 
INTERNATIONAL JOURNAL OF ACADEMIC RESEARCH IN BUSINESS AND SOCIAL SCIENCES

Vol. 10, No. 4, April, 2020, E-ISSN: 2222-6990 C 2020 HRMARS

\section{The Lawful Residence}

A lawful residence is the place where the husband prepares as his wife's residence to fulfill the conditions of the Shari'ah so that it becomes obligatory on the wife to obey him by dwelling where he places her. If she refuses, then she becomes disobedient and no right to alimony (Hasbullah, n.d).

although alimony is obligatory from the husband to the wife, shelter is a part of the alimony, and this why the husband must provide a shelter for his wife. This comprises all facilities according to his condition and status. Allah says: "...let the women live(in iddah) in the same style as ye live, according to your means" (al-Talaq: 6). He also says: "...on the contray live with them on a footing of kindness and equity" (al-Nisa': 19). One of the requirements is that he houses her away from the public eyes, to save her belongings, for kind relation and filial enjoyment (Ibn-Qudamah ,1405/11: 209).

\section{The Rights of The Husband on His Wife}

The rights of the husband on the wife, on the other hand, can be divided into the following:

\section{a. Obedience}

According to the hadeeth that is prescribed by shari'ah, it is obligatory upon the wife to obey her husband, as stated in the verse: "Men are protectors and maintainers of women, because Allah has given the one more (strength) than the other, and because they support them from their means..." (al-Nisa': 34). The husband should be able to control, train, and house the wife, and avoid her from being vulgar, and it is imperative on the wife to obey him and accept his command unless it leads to disobedience of Allah SWT (Al-Qurtubi, n.d./3: 153).

It was narrated by Abu Hurayrah (may Allah be pleased with him) who said that the Messenger of Allah (peace and blessings of Allah be upon him) said: "If a woman observes her five times daily prayers, fasts her month of Ramadan, guards her human private dignity, and obeys her husband, she would enter the paradise through any entrance she prefers" (Ibn-Hanbal, 3: 1661).

b. The Mandate to Discipline/Train

This is based on the non-obedience of the wife to her husband. Nushuz is defined as disobedience to the husband where Allah has imposed that he be obeyed (IbnQudamah 1405H).

And the Islamic Shari'ah law has observed the various women's natures in this regard. Some of them accept correction through simple signal and gaze, and some others require quite more than that, such as admonition, while there are amongst women who do not respond to correction except through abandoning them in bed or light beating. Allah says: “...As to those women on whose part ye fear disloyalty and ill-conduct admonish them(first).(Next) refuse to share their beds.(And last) beat them(lightly); but if they return to obedience, seek not against them means(of annoyance), for Allah is Most High, Great above you all" (al-Nisa': 34). So, the treatment of disobedience is as indicated in the verse; admonition, abandonment and light beating. 
INTERNATIONAL JOURNAL OF ACADEMIC RESEARCH IN BUSINESS AND SOCIAL SCIENCES Vol. 10, No. 4, April, 2020, E-ISSN: 2222-6990 @ 2020 HRMARS

c. The Staying at Home

The Islamic Shari'ah law enjoins the husband to take care of his wife, because she is confined to the right of the husband. He has the right to forbids her from working, and it is obligatory that she remains in her house and does not go out of the house without his permission, after being provided with a lawful settlement. Allah says: "And stay quietly in your houses, and make not a dazzling display, like that of the former Times of Ignorance"(al-Ahzab: 33). The order here is for the women to remain at home (Al-Qurtubi, n.d./7: 482).

d. The Service of the Woman to her Husband

It is important that the wife prepares meals, such as grains, bread, and cooking, for her husband. This is the opinion of some of Hambali jurists (Ibn Qudamah 1405, 9: 696), and the view of the Hanafi scholars (al-Kasani, 1986), and the Malikis (al-Dasuki, n.d.).

They base their opinions on the statement "..."And women shall have rights similar to the rights against them, according to what is equitable but men have a degree(of advantage) over them..." (al-Baqarah: 228), The 'reasonable' that Allah commands on the Wives towards their husbands is 'the servitude' (Ibn al-Qayyim, 1994, 4: 80). Allah also says: "Men are the protectors and maintainers of women" (surah al-Nisa': 34). There is evidence here that the guardianship is to man over women. If it is said that the man must serve and take care of the house internally, as he does externally, then the guardianship would for her and not for him (Ibnal-Qayyim, 1994).

\section{The Common Rights Between Spouses}

Besides the reciprocal rights against each other, Islam has also joins the common rights of both the husband and the wife.

\section{a. Good Relationship}

Good relationship, based on love and affection, is regarded as one of the common rights of spouses, by each striving to make the other happy, for Allah says: "..."And women shall have rights similar to the rights against them, according to what is equitable but men have a degree(of advantage) over them"(al-Baqarah: 228), meaning that they have rights to companionship and reasonable affection from their husbands, similar to those resposibilities hanging on them towards their husbands (alQurtubi, n.d.). Allah also says: ...on the contray live with them on a footing of kindness and equity" (al-Nisa': 19). There is in this glorious verse the order on men to honourably relate with their wives, and it is of the 'honourable' that he fulfils her rights, such as the dower, alimony, and housing, as well as avoid hurting and insulting her. He should also not abandon her, and should not frown at her without having done anything wrong (al-Jassas, 1405H/2: 157).

The Prophetic tradition also encourages the wife to obey, regard and respect her husband, as related by Qays ibn Sa'd that the Messenger of Allah (peace and blessings of Allah be upon him) said: "If I could order anyone to prostrate to the other, I would have ordered women to prostrate to their husbands, for the role and responsibilities Allah has preferred to the husbands over them" (AbuDawud, 1975/2: 2140). 
INTERNATIONAL JOURNAL OF ACADEMIC RESEARCH IN BUSINESS AND SOCIAL SCIENCES Vol. 10, No. 4, April, 2020, E-ISSN: 2222-6990 @ 2020 HRMARS

b. The Right to Filial Enjoyment

The wife should allow her husband full access to her; she should not expose him to the temptation of look forward to another woman through preventing herself from him. The Prophet (peace and blessings of Allah be upon him) has warned against that in an hadis related by Abu Hurayrah that the Prophet (peace and blessings of Allah be upon him) said: "If a woman sleeps neglecting her husband's bed, the angels would curse her until she wakes" (Muslim, 1334H/2: 1436)

The husband should as well allow her wife full access to him, as much as possible, in order to avoid her looking outward to anyone else. Ibn Abbas (may Allah be pleased with him) said: "I love to adorn myself for my wife as I would like my wife to adorn herself for me" (al-Qurtubi, n.d./3: 90).

c. The Sanctity of Collateral Affinity

Collateral affinity is considered a strong bond, as it makes the wife part of the husband's family and the husband a member of the wife's family. Her mother becomes his mother and his father becomes her father, and she is often call him the way she calls on her own father, and the wife's daughter is in the place of a daughter. This is what common sense dictates, and the sanctity of collateral affinity have come in line with the common sense. Thus, the wife becomes forbidden to the fathers of her husband, the male children of her husband and their descendants. And similarly, the husband becomes forbidden to his wife's mothers, daughters, and their descendants as well.

Accordingly, this shows that the sanctity of collateral affinity is consistent with the objectives of the Shari'ah in guiding human instinct towards true happiness. The goal of collateral affinity is closeness, affection, and friendliness. So, if there exists no prohibitions in collateral affinity it would lead to severance of family ties, instability and disintegration of marital life.

\section{Conclusion}

The Islamic Shari'ah law has adopted many provisions that guarantee the permanence and continuity of marriage, to guide the family to the desired happiness, and away from divorce. The Islamic Shari'ah has initiated a series of preventive legal measures to maintain the permanence of marriage tie, both before and after the wedding, to build a family surrounded with love and interdependence. The research arrived at the legal perception of the preventive legal procedures before the marriage tie, which includes:

i. It established the choice of each of the spouses to the other, in the sense that the woman be of good character, religion, virgin, productive, reasonable and affordable dower, and the need to have the consent of the woman to the suitor.

ii. The necessity of respecting the medical examination outcome, to ensure the health of the spouses and their future children.

iii. Respecting the pre-marital engagement, for proper acquaintance of the spouses and their families.

The research also arrived at the legal perception of preventive legal procedures after the wedding, which includes: 
i. The protection of the wife's right to her husband in dower, alimony and shelter, as much as the husband could afford.

ii. The protection of the husband's right to his wife in obedience, discipline and settlement at home in service to him.

iii. The protection of common rights of the spouses in kindly relation, the permissibility of filial enjoyment and the sanctity of collateral affinity.

If Muslim couple take the precautionary measures into consideration, the Islamic law will lead them to happy family in which the objective, affection and trust will be achieved, thereby reducing the incidence of arguments and disputes that may lead to divorce. Where Malaysian law is concern, it is always the intention of the law to protect the marital institution. Preventive measures against divorce are adopted in the law pre and post marriage. However, in a situation where the court thinks that a marriage fails to achieve its objective or that a marriage proved to be detrimental to either spouse, an application to dissolve the marriage will be allowed.

\section{Acknowledgement}

Special thanks go to the Research Management, Innovation and Commercialization Centre (RMIC), Universiti Sultan Zainal Abidin for the funding.

\section{Corresponding Author}

Sharifah Norshah Bani Syed Bidin,Ph.D

Faculty of Islamic Contemporary Studies, Universiti Sultan Zainal Abidin, Kampus Gong Badak, 21300 Kuala Nerus, Terengganu, Malaysia.

E-Mail: sharifahns@unisza.edu.my

\section{References}

AbuDawud, S. (1975). Sunan Abi Dawud. Riyadh: Maktabah al-Ma'arif. AbuZahra, M. (n.d). Al-Ahwal al-Shakhsiyyah. Cairo: Dar al-Fikr al-'Arabi.

Al-Dasuki, M. A. (n.d). Hashiyah al-Dasuki 'ala al-Sharh al-Kabir. N.P: Dar al-Fikr.

AL-Ghazali, A. H. (n.d). Ihya' ulum al-Din. Beirut: Dar al-Fikr.

Al-Haythami, N. D. (1994). Majma' al-Zawa'id wa manba' al-Fawa'id. Beirut: Dar al-Kitab al-'Arabi. Al-Jassas, A. B. (1405). Ahkam al-Qur'an. Beirut: Dar Ihya' Turath al-'Arabi.

Al-Kasani, A. B. (1886). Bada'i' al-Sana'l' fi tartib al-Shara'l'. Beirut: Dar al-Kutub al-'llmiyyah.

Al-Omrani, Y. (2000). Al-Bayan fi Madhhab al-Imam al-Shafi'i. Beirut: Dar al-Minhaj.

Al-Qurtubi, A. A. (n.d). Al-Jami' li Ahkam al-Qur'an. Beirut: Dar Ihya' al-Turath al-'Arabi.

Amato, P. R. (2003). People's Reasons for Divorcing, Journal Of Family Issues, Vol. 24 No. 5, July 2003, SAGE Publication, 602-626

Gillian, P. (1993). Disability, Caring and Marriage: The Experience of Younger Couples when a Partner is Disabled after Marriage, The British Journal of Social Work, Volume 23, Issue 6, 1 December 1993, 565-580

Hisbullah, A. (n.d). Al-Zawaj fi Shari'ah al-Islamiyyah. Cairo: Dar al-Fikr al-'Arabi.

Hossam, A. (2017). Jordan Is The Highest Arab Country In The Rate of Divorce. Retrieved from www.addustour.com/articles/940326 
INTERNATIONAL JOURNAL OF ACADEMIC RESEARCH IN BUSINESS AND SOCIAL SCIENCES

Vol. 10, No. 4, April, 2020, E-ISSN: 2222-6990 @ 2020 HRMARS

IbnAbidin, M. A. (1966). Hashiyah Radd al-Muhtar. Beirut: Dar al-Ma'rifah.

Ibn-al-Qayyim, M. (1994). Zaad al-Ma'ad fi Hudaa Khayr al-'lbaad. Beirut: Mu'assasah al-Risalah.

Ibn-Hanbal, A. (2001). Musnad al-Imam Ahmad bin Hanbal. Beirut: Mu'assasah al-Risalah.

Ibn-Majah, M. (n.d). Sunan Ibn Majah. Riyadh: Maktabah al-Ma'arif.

IbnQudaamah, M. (1405). Al-Mughni. Beirut: Dar al-Fikr.

Khairuldin, W. M. K. F. B. W., Embong, A. H., Hassan, S. A., Yasin, M. F. M., \& Anas, W. N. I. W. N. (2019). Strategic management in fatwa-making process. Academy of Strategic Management Journal, 18(4), 1-6.

Muslim, A. H. (1334). Al-Jami' al-Musamma Sahih Muslim. Beirut: Dar al-Jayl.

Nimtz, M. A. (2011). Satisfaction and contributing factors in satisfying long-term marriage: A phenomenological study.

Sharbini, S. D. (1994). Mughni al-Muhtaj. Beirut: Dar al-Fikr.

South, S., \& Spitze, G. (1986). Determinants of Divorce over the Marital Life Course. American Sociological Review, 51(4), 583-590.

Syahidi, B. (2017). 171,252 Kes Cerai Pasangan Islam retrieved from http://www.utusan.com.my/berita/wilayah/kl-putrajaya/171-252-kes-cerai-pasangan-islam1.536513.

Tadamun. (2017). Early Divorce in Jordan: Fact Sheet. Retrieved from http://sigijordan.org/ar/?p=3724

Yasin, M. F. B. M., Embong, A. H., Khairuldin, W. M. K. F. W., Rahim, A., Abdullah, Sulaiman, R., Mutalib, N. A. (2018). Contributions of technology towards development of Qur'anic tajweed knowledge. International Journal of Civil Engineering and Technology, 9(6), 1340-1352.

Zemp M., Bodenmann G. (2018) Family Structure and the Nature of Couple Relationships: Relationship Distress, Separation, Divorce, and Repartnering. In: Sanders M., Morawska A. (eds) Handbook of Parenting and Child Development Across the Lifespan. Springer, Cham. 